\title{
The association of depression with child abuse among Indonesian adolescents
}

\author{
Meita Dhamayanti ${ }^{*}$ (D, Anindita Noviandhari ${ }^{1}$, Nina Masdiani ${ }^{2}$, Veranita Pandia ${ }^{2}$ and Nanan Sekarwana ${ }^{1}$
}

\begin{abstract}
Background: Depression is one of the most prevalent mental health problems among adolescents. Mental health problems might be the result of child abuse considering that their prevalences are increasing simultaneously in Indonesia. The aim of this study was to determine the association between depression and a history of abuse among adolescents.

Methods: An analytic cross-sectional study was conducted on 786 junior high school students from Bandung City, West Java, Indonesia. Subjects were selected using two-stage cluster sampling. The Children's Depression Inventory (CDI) and the ISPCAN Child Abuse Screening Tool (ICAST) questionnaires were applied to assess depression and a history of abuse, respectively. Depression was diagnosed by a psychiatrist after a positive score on the CDI. The data were analysed using chi-square tests and multiple regression.
\end{abstract}

Results: A history of child abuse was associated with depression in adolescents. All dimensions of child abuse had a significant association with depression. Psychological violence had the highest risk factor for the occurrence of depression ( $P R=6.51$ ), followed by exposure to violence and physical violence. Sexual violence was not a common dimension of child abuse among students. Psychological violence had the strongest association with depression, and victims were three times more likely to develop depression ( $P O R=3.302, p=0.004$ ).

Conclusion: Psychological violence was proven to be a strong risk factor for developing depression symptoms among adolescent students. While each victimization domain remained a significant predictor of depression, the experience of multiple domains during a child's life-course may predict mental health risk. Early detection and interventions to prevent abuse and its consequences are critical.

Keywords: Adolescents, Child abuse, Depression, Indonesia

\section{Background}

Child abuse includes all forms of physical and mental child abuse, sexual abuse, neglect or negligent treatment, and commercial or other exploitation that has a high likelihood of resulting in actual or potential harm to the child's health, survival, development, dignity, responsibility, beliefs and/or rights [1-3]. The prevalence of child abuse is increasing [4]. Meta-analyses have provided a

\footnotetext{
*Correspondence: meita.dhamayanti@unpad.ac.id

'Department of Child Health, Faculty of Medicine, Hasan Sadikin Hospital, Universitas Padjadjaran, Jalan Pasteur No. 38, Pasteur, Sukajadi, Kota Bandung, Jawa Barat 40161, Indonesia

Full list of author information is available at the end of the article
}

series of overall estimations of $17.7,26.7,11.8$ and $16.3 \%$ for physical abuse, psychological abuse, sexual abuse, and neglect, respectively [5-7]. The Indonesian Commission of Child Protection [8] reported an increase in violence from 2.178 cases in 2011 to 6.006 in 2015. In terms of the setting of violence, $91 \%$ occurred at home, $87.6 \%$ at school, and $17.9 \%$ in the community [8].

A history of violence against children might lead to mental health disorders, such as depression, psychosis, anxiety and post-traumatic disorder $[9,10]$. Depression is one of the mental health problems that commonly occur in adolescents. Currently, approximately 2 to $3 \%$ of children and $8 \%$ of adolescents have experienced

(c) The Author(s). 2020 Open Access This article is licensed under a Creative Commons Attribution 4.0 International License, which permits use, sharing, adaptation, distribution and reproduction in any medium or format, as long as you give appropriate credit to the original author(s) and the source, provide a link to the Creative Commons licence, and indicate if changes were made. The images or other third party material in this article are included in the article's Creative Commons licence, unless indicated otherwise in a credit line to the material. If material is not included in the article's Creative Commons licence and your intended use is not permitted by statutory regulation or exceeds the permitted use, you will need to obtain permission directly from the copyright holder. To view a copy of this licence, visit http://creativecommons.org/licenses/by/4.0/ The Creative Commons Public Domain Dedication waiver (http://creativecommons.org/publicdomain/zero/1.0/) applies to the data made available in this article, unless otherwise stated in a credit line to the data. 
depression. The lifetime prevalence of depressive disorders in adolescents is estimated to be $17 \%$ [11].

Adolescents with depression may become a burden on their families and themselves. The impact of depression is not only detrimental to the child and family but also a national burden [12]. Adolescents with depression may have a higher risk of decline in academic performance, interpersonal relations, and suicide [13]. A history of child abuse at the age of 10 to 17 years is the strongest predictor of depression, adolescents who experience violence in school and at home have the highest risk of depressive disorders in society $[14,15]$. In most cases, child abuse by a caregiver or parent at home is the form of victimization that has the strongest independent association with depression [14].

West Java is one of thirty-four provinces in Indonesia. It has a $9.3 \%$ prevalence of mental emotional problems in adolescents above 15 years of age while Indonesia's national rate is at 6\% [15]. Accordingly, this research aimed to analyse the relationship between a history of child abuse and depression in adolescents in West Java, Indonesia.

\section{Methods}

\section{Study design}

A cross-sectional study was conducted on junior high school students. A two-stage cluster sampling was performed to determine the school and the subjects. First, several schools were selected randomly, and then the adequate number of students was determined by a simple random sampling method. A minimum sample size of 770 students was needed in this study (99\% power and 95\% significance interval). The study was conducted from May to December 2016.

A letter of approval from the Provincial Directorate of National Education of the city where the research took place was obtained prior to the study. Ethical approval was issued by the Health Research Ethics Committee Faculty of Medicine, Universitas Padjadjaran 29/ UN6.C1.3.2/KEPK/PN/2016.

\section{Tools}

Depression was assessed using the Children's Depression Inventory (CDI) $[16,17]$ as well as interviews for the application of a diagnosis based on the criteria of the DSM $\mathrm{V}$ diagnostic criteria. Depression criteria were determined by the answers to the questionnaire. Later, with the determination of a CDI score $\geq 19$, an interview was carried out by a psychiatrist based on the DSM V diagnostic criteria. The CDI instrument itself has been validated in an Indonesian version [18].

To assess any history of child abuse, we used the ICAST-C questionnaire $[19,20]$, which has been validated in an Indonesian version [21]. The ICAST-C consists of 55 questions covering 5 dimensions of abuse: violence (9 questions), physical (19 questions), psychological (17 questions), neglect (6 questions), and sexual (4 questions). Scores for each question were interpreted as follows: $1=$ if there is a history of violence and $0=$ if there is no history of violence. A cut-off point was selected using the mean value of the history of child abuse data. Subjects with a total score of child abuse dimensions below the cut-off point were not categorized as experiencing child abuse.

For the correlation validity test, we compared the items correlation value with the reference value by taking $5 \%$ of the number of respondents (45) as the a value. The result was 0.294 . The results showed that all items in the ICAST-C had adequate validity. Based on the Kuder-Richardson reliability test method, the ICAST-C instrument showed strong reliability $(K R 20=0.92$ and $\mathrm{KR} 21=0.87$ ).

\section{Data analysis}

Descriptive tests with numeric and percentage value presentation were used to analyse the results of the CDI and I-CAST. Analytic Chi-square tests were used to analyse the differences of socio-demographic characteristics of students among subjects with depression and associations between the scores of both instruments. Bivariate analysis between the histories of child abuse with depression was tested with the Prevalence Ratio (PR). Multivariate tests were applied to determine which type of abuse was the most correlated with depression. The results were considered significant if the $p$ value was < 0.05. Data management and analysis were conducted using SPSS (Statistical Package for Social Science) 15.0.

\section{Results}

A total of 845 students from 23 junior high schools gave their consent; however, only 835 filled out a questionnaire. After examining the questionnaire, 786 students participated in this study (Fig. 1). Students were from the 7 th grade $(34.86 \%)$, 8th grade $(36.51 \%)$, and 9th grade $(28.63 \%)$ of junior high school. There was an almost equal proportion of male and female students, at $441(56.11 \%)$ and 345 (43.89\%), respectively. The age range was $12-16$ years old, with a mean age of 13 years old. A total of $43(5.47 \%)$ subjects with a CDI score $\geq 19$ were subsequently interviewed by a psychiatrist and met the DSM-V criteria of depression. There were no significant differences of students' socio-demographic characteristics among depressed and non-depressed subjects (Table 1).

A history of child abuse was determined by the statistical mean rate of the child abuse score. A subject with scores above the mean value was categorized as having a 


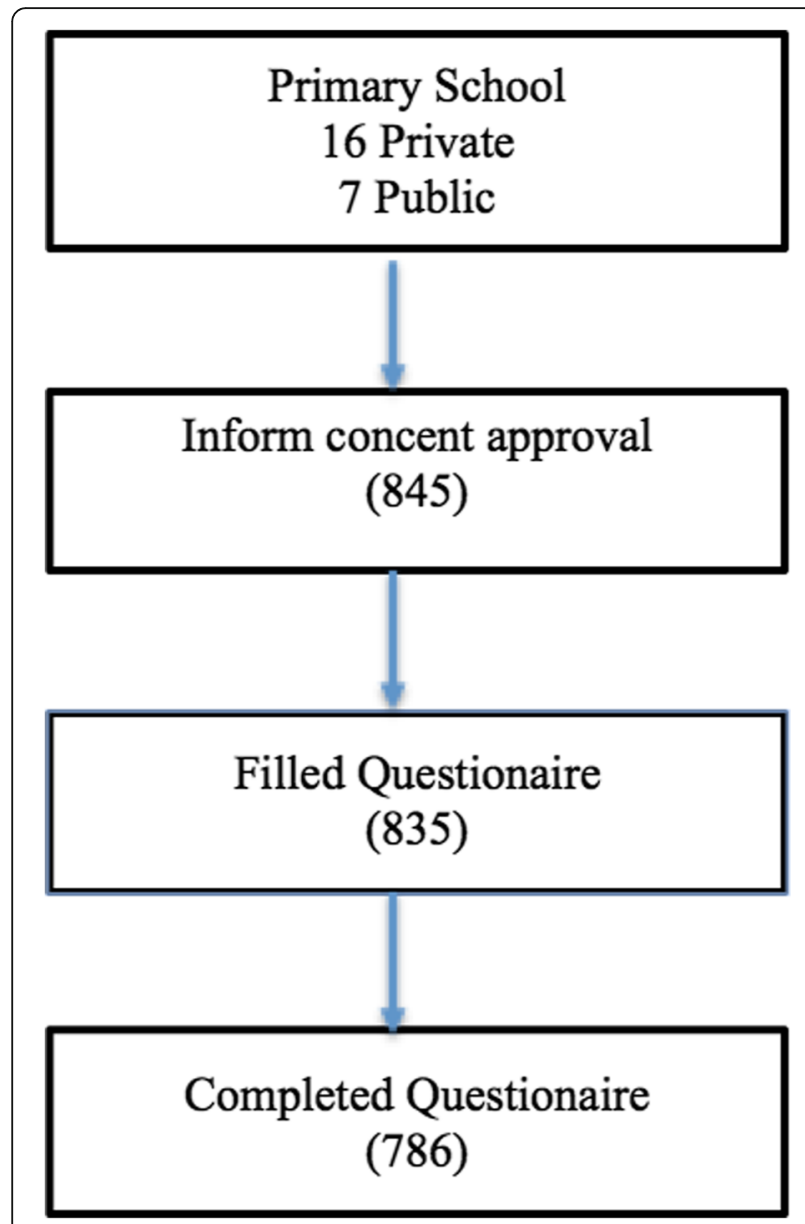

Fig. 1 Sample Selection

history of child abuse. There were 367 subjects (46.7\%) with a history of child abuse, as shown in Table 2.

A total of 27 (3.43\%) subjects with depression had an experience of child abuse. A significant association was found between depression and a child abuse history ( $p=$ 0.03) (see Table 2).

There were subjects with a history of psychological victimization $(474,60.3 \%)$, exposure to violence (354, $45 \%$ ), physical victimization (321, 40.8\%), neglect (313, $39.8 \%$ ) and sexual victimization (172, 21.9) (Table 3). Based on bivariate analysis, all 5 dimensions of child abuse history were associated with depression. Subjects with a psychological victimization history were 6.51 times more likely to develop depression, while those with neglect were three times more likely to develop depression (Table 3).

Since bivariate analysis had shown an association of all dimensions with depression, multivariate analysis was conducted to find the dimension with the strongest association with depression using logistic regression tests. The results shown in Table 4 indicate that psychological violence has the strongest association. Adolescents with a history of psychological violence were three times more likely to develop depression $(\mathrm{POR}=3.302, p=$ 0.004).

\section{Discussion}

This study revealed that child abuse was quite common among junior high school students in Bandung, West Java, Indonesia. Approximately $46.69 \%$ of our subjects had a history of child abuse. Indonesia itself has no definite data about child abuse so far. However, this current study showed a history of victimization in psychological dimensions was the most widely experienced by the students $(60.3 \%)$, followed by exposure to violence (45\%), physical victimization (40.8\%) and neglect (39.8\%). On the other hand, sexual victimization was relatively uncommon (21.88\%).

Epidemiological data from a study in India showed that the highest prevalence of violence experienced was psychological (61.9\%), physical (21.43\%) and sexual (16.67\%) [22]. Meanwhile, data from the United States for 686,000 cases of children violence showed that neglect was the most common (78.6\%), followed by physical abuse (18.3\%) and sexual violence (9.3\%) [22]. However, several studies showed the cumulative prevalence based on a survey of communities were approximately $15-30 \%$ for girls and $5-15 \%$ for boys for sexual violence, $5-35 \%$ for physical violence, $4-9 \%$ for psychological violence and $6-12 \%$ for neglect [22].

Most of the subjects were seventh grade students who were in the early adolescent phase (ages 11 to 14) and were typically very egocentric with poor self-regulation [23]. These young adolescents were mostly emotionally victimized at school. School violence played an important role in developing depression [12, 24]. Meanwhile, conduct disorder has its highest prevalence in adolescents, namely, $7 \%$ in adolescents aged 12 to 16 years old [25].

This study showed all child abuse dimensions had significant associations with depression. This is similar to prior studies that asserted the existence of a correlation between histories of violence against children with depression [26, 27]. Therefore, while different forms of victimization frequently co-occur, they each make unique additional contributions towards an increased risk for mental health problems [14].

Subjects with a history of psychological child abuse had a 6.51 times higher risk of depression. This finding is similar to a meta-analysis that stated abuse and neglect were strongly associated with depressive disorder in adolescence [24]. Moreover, Pirdehghan's study in Iran showed a correlation between mental disorders and violence (Spearman rho: 0.2; $p$-value $<0.001$ ) as well [28].

We found that depressive symptoms on the CDI were strongly associated with all dimensions of child abuse, 
Table 1 The socio-demographic comparison among depressed and non-depressed subjects

\begin{tabular}{|c|c|c|c|}
\hline \multirow[t]{2}{*}{ Characteristics } & \multicolumn{2}{|l|}{ Depression } & \multirow[t]{2}{*}{$p$} \\
\hline & No $(\boldsymbol{n}=743)$ & Yes $(\boldsymbol{n}=43)$ & \\
\hline Age & & & $0.168^{* *}$ \\
\hline Mean & 13.36 & 13.56 & \\
\hline SD & 0.926 & 0.881 & \\
\hline Median & 13.0 & 13.0 & \\
\hline \multirow[t]{2}{*}{ Range } & $12-16$ & $12-15$ & \\
\hline & $n(\%)$ & $\mathrm{n}(\%)$ & \\
\hline \multicolumn{4}{|l|}{ Sex } \\
\hline Male $(N=441)$ & $420(95.2)$ & $21(4.8)$ & $0.323^{*}$ \\
\hline Female $(N=345)$ & $323(93.6)$ & $22(6.4)$ & \\
\hline \multicolumn{4}{|l|}{ Grade } \\
\hline 7 th $(N=274)$ & $263(96.0)$ & $11(4.0)$ & \\
\hline 8th $(N=287)$ & $270(94.1)$ & $17(5.9)$ & $0.395^{*}$ \\
\hline 9th $(N=225)$ & $210((3.3)$ & $15(6.7)$ & \\
\hline \multicolumn{4}{|l|}{ Father's Education } \\
\hline Primary School $(\mathrm{N}=74)$ & 70 (94.6) & $4(5.4)$ & \\
\hline Junior High School N = (82) & $79(96.3)$ & $3(3.7)$ & \\
\hline Senior High School $(N=300)$ & $285(95.0)$ & $15(5.0)$ & $0.802^{*}$ \\
\hline College and higher (+ 324) & $303(93.5)$ & $21(6.5)$ & \\
\hline Illiterate $(N=6)$ & $6(100.0)$ & 0 & \\
\hline \multicolumn{4}{|l|}{ Mother's Education } \\
\hline Primary School $(N=75)$ & $73(97.3)$ & $2(2.7)$ & \\
\hline Junior High School(N=102) & $100(98.0)$ & $2(2.0)$ & \\
\hline Senior High School $(N=329)$ & $310(94.2)$ & $19(5.8)$ & $0.202^{*}$ \\
\hline College and higher $(N=272)$ & $252(92.6)$ & $20(7.4)$ & \\
\hline Illiterate $(N=8)$ & $8(100.0)$ & 0 & \\
\hline \multicolumn{4}{|l|}{ Father's Occupation } \\
\hline Public Servant $(N=295)$ & $279(94.6)$ & $16(5.4)$ & \\
\hline Entrepreneur $(N=337)$ & $321(95.3)$ & $16(4.7)$ & $0.556^{*}$ \\
\hline Labourers/Farmers/Others $(N=154)$ & $143(92.9)$ & $11(7.1)$ & \\
\hline \multicolumn{4}{|l|}{ Mother's Occupation } \\
\hline Public Servant $(N=116)$ & $107(92.2)$ & $9(7.8)$ & \\
\hline Entrepreneur $(N=145)$ & 137 (91.9) & $12(8.1)$ & $0.181^{*}$ \\
\hline Labourers/Farmers/Others $(N=54)$ & $51(94.4)$ & $3(5.6)$ & \\
\hline Housewife $(N=467)$ & 448 (95.9) & $19(4.1)$ & \\
\hline
\end{tabular}

$p$ value using ${ }^{*}$ Chi-square test and ${ }^{* *} \mathbf{T}$ test

Table 2 Association between depression and child abuse history

\begin{tabular}{llll}
\hline Child abuse & Depression & & p \\
\cline { 2 - 3 } & No $(n=743)$ & Yes $(n=43)$ & \\
\hline No $(n=419)$ & $403(51.27 \%)$ & $16(2.04 \%)$ & $0.030^{*}$ \\
Yes $(n=367)$ & $340(43.26 \%)$ & $27(3.43 \%)$ & \\
\hline
\end{tabular}

*Chi-square $p<0.05$ particularly psychological violence and neglect. In one review of 124 studies, psychological violence increased the risk of depression by an odds ratio of 3.06, whereas physical abuse increased the risk of depression by only half that amount. Furthermore, psychological violence abuse was more closely related to depression severity than sexual or physical abuse [10].

Emotional abuse and neglect may alter the development of reward and oxytocin systems in childrens' 
Table 3 Association between depression and dimensions of child abuse

\begin{tabular}{|c|c|c|c|c|c|}
\hline \multirow[b]{2}{*}{ Child abuse dimension } & \multicolumn{2}{|l|}{ Depression } & \multirow{2}{*}{$\begin{array}{l}p- \\
\text { value }\end{array}$} & \multirow[t]{2}{*}{ PR } & \multirow[t]{2}{*}{$95 \% \mathrm{Cl}$} \\
\hline & $\begin{array}{l}\text { No } \\
\text { n (\%) }\end{array}$ & $\begin{array}{l}\text { Yes } \\
\text { n (\%) }\end{array}$ & & & \\
\hline Psychological victimization & $438(55.73)$ & $36(4.58)$ & $0.00^{* *}$ & 6.51 & $2.85-14.81$ \\
\hline Violence exposure & $322(40.9)$ & $32(4.07)$ & $0.00^{* *}$ & 3.80 & $1.88-7.66$ \\
\hline Physical victimization & $291(37.02)$ & $30(3.82)$ & $0.00^{* *}$ & 3.58 & $1.84-6.98$ \\
\hline Neglect & $285(36.26)$ & $28(3.56)$ & $0.00^{* *}$ & 3.00 & $1.57-5.71$ \\
\hline Sexual victimization & 154 (19.59) & $18(2.29)$ & $0.00^{* *}$ & 2.75 & $1.46-5.18$ \\
\hline
\end{tabular}

Note: * Chi-square test; $P R$ Prevalence risk

brains, leading to impaired parental care giving in the subsequent generation [29].

These findings were confirmed in a recent systematic review and meta-analysis, although most of the data came from retrospective cross-sectional studies or longitudinal designs that relied on self-reported abuse [30]. Sexual violence showed a far weaker association. There are several possible explanations, such as that it may be underreported because of stigma [31].

Practitioners should be aware that violence during childhood might result in negative consequences in adolescents. Therefore, a good understanding is required to prevent violent acts against children that might allow effective interventions into violence issues in adolescents [32, 33].

\section{Conclusions}

A history of child abuse has a correlation with depression in adolescents. Psychological child abuse had the highest risk for the onset of depression compared to other violent dimensions. However each victimization domain remained a significant predictor of depression, the experience of multiple domains during a child's lifecourse may predict mental health risk. Early detection and interventions to prevent abuse and its consequences are critical.

Table 4 Multivariate regression between depression and child abuse dimensions

\begin{tabular}{lcccc}
\hline Variable & coeff B & SE (B) & $p$ value & POR $_{\text {adj }}(95 \% \mathrm{Cl})$ \\
\hline First model: & & & & \\
$\quad$ Psychological & 0.854 & 0.453 & 0.060 & $2.348(0.966-5.708)$ \\
Violence exposure & 0.902 & 0.427 & 0.035 & $2.464(1.068-5.684)$ \\
$\quad$ Physical & 0.463 & 0.391 & 0.237 & $1.589(0.738-3.421)$ \\
$\quad$ Neglect & 0.242 & 0.337 & 0.472 & $1.274(0.658-2.466)$ \\
$\quad$ Sexual & 0.437 & 0.342 & 0.202 & $1.548(0.792-3.027)$ \\
Last model: & & & & \\
$\quad$ Psychological & 1.195 & 0.414 & 0.004 & $3.302(1.466-7.438)$ \\
$\quad$ Violence exposure & 1.096 & 0.415 & 0.008 & $2.993(1.328-6.747)$ \\
\hline
\end{tabular}

\section{Limitations}

We recognized that a diagnosis of depression might be over-represented by the adolescent students fulfilling the questionnaires. To better reflect the accuracy of this diagnosis, psychiatrists were used to determine those that met the DSM-V criteria for depression.

\section{Abbreviations}

CDI: Children's Depression Inventory; ISPCAN : International Society for Prevention of Child Abuse and Neglect; ICAST: ISPCAN Child Abuse

Screening Tool; DSM-V: Diagnostic and Statistical Manual of Mental Disorders V; ICAST-C: ISPCAN Child Abuse Screening Tool Children's Version; KR: KuderRichardson; SPSS: Statistical Package for the Social Sciences; PR: Prevalence Ratio; POR: Prevalence Odds Ratio

\section{Acknowledgements}

The authors express their gratitude to the Health System Research Center, Faculty of Medicine, Universitas Padjadjaran, for contributing to the ICAST-C instrument. The authors also express thanks to various participating schools, parents and children who were involved in this study.

\section{Authors' contributions}

$M D, N M$ and VP were responsible for the conception and design of the study, acquisition of data, analysis, and interpretation of data writing and revising the manuscript. AN contributed to the analysis and interpretation of data as well as writing and revising the manuscript. NS contributed to the conception and design of the study, acquisition of data, analysis of data, interpretation of data, and writing the manuscript. All authors read and approved this manuscript.

\section{Funding}

The author(s) disclosed receipt of an Internal Grant of Universitas Padjadjaran for financial support of the research, authorship, and/or publication of this article.

\section{Availability of data and materials}

All data and materials of this study are available at the Faculty of Medicine, Universitas Padjadjaran, Bandung, Indonesia, by contacting the corresponding author Meita Dhamayanti, email meita.dhamayanti@unpad.ac.id

\section{Ethics approval and consent to participate}

Ethical approval was issued by the Health Research Ethics Committee Faculty of Medicine, Universitas Padjadjaran 29/UN6.C1.3.2/KEPK/PN/2016. Written informed consent was obtained from the subjects and parents or guardians.

Consent for publication

Not applicable.

\section{Competing interests}

The author(s) declared no potential conflicts of interest with respect to the research, authorship, and/or publication of this article. 


\section{Author details}

1Department of Child Health, Faculty of Medicine, Hasan Sadikin Hospital, Universitas Padjadjaran, Jalan Pasteur No. 38, Pasteur, Sukajadi, Kota Bandung, Jawa Barat 40161, Indonesia. ${ }^{2}$ Department of Psychiatry, Faculty of Medicine, Hasan Sadikin Hospital, Universitas Padjadjaran, Jalan Pasteur No. 38, Pasteur, Sukajadi, Kota Bandung, Jawa Barat 40161, Indonesia.

Received: 1 March 2020 Accepted: 22 June 2020

Published online: 27 June 2020

\section{References}

1. UNICEF. Convention on the Rights of the Child. 1989

2. $\mathrm{WHO}$ and ISPCAN. Preventing child maltreatment: a guide to taking action and generating evidence. Geneva: WHO Press; 2006.

3. Gilbert R, Fluke J, O'Donnell M, Gonzalez-Izquierdo A, Brownell M, Gulliver P, et al. Child maltreatment: variation in trends and policies in six developed countries. Lancet. 2012;379(9817):758-72.

4. Krug EG, Mercy JA, Dahlberg LL, Zwi AB. The world report on violence and health. Lancet. 2002;360(9339):1083-8.

5. Stoltenborgh M, Bakermans-Kranenburg MJ, van ljzendoorn MH, Alink LR. Cultural-geographical differences in the occurrence of child physical abuse? A meta-analysis of global prevalence. Int J Psychol. 2013;48(2):81-94.

6. Stoltenborgh M, Bakermans-Kranenburg MJ, van ljzendoorn $\mathrm{MH}$. The neglect of child neglect: a meta-analytic review of the prevalence of neglect. Soc Psychiatry Psychiatr Epidemiol. 2012;48(3):345-55.

7. Stoltenborgh M, Bakermans-Kranenburg MJ, Alink LRA, van ljzendoorn MH. The universality of childhood emotional abuse: a meta-analysis of worldwide prevalence. J Aggress Maltreat Trauma. 2012;21(8):870-90.

8. Komisi Perlindungan Anak Indonesia. Profil Komisi Perlindungan Anak Indonesia. [cited 2015 July 1]. Available from https://www.kpai.go.id/profil.

9. Danese A, McCror E. Child maltreatment. In: Thapar A, Pine DS, Leckman JF, Scott S, Snowling MJ. Rutter's Child and Adolescent Psychiatry. 6th. Wiley; 2015. p.364-375.

10. Norman RE, Byambaa M, De R, Butchart A, Scott J, Vos T. The long-term health consequences of child physical abuse, emotional abuse, and neglect: a systematic review and meta-analysis. PLoS Med. 2012;9(11):e1001349.

11. Kessler RC, Avenevoli S, Costello EJ, Green JG, Gruber MJ, Heeringa S, et al. National Comorbidity Survey Replication Adolescent Supplement (NCS-A): II. Overview and design. J Am Acad Child Adolesc Psychiatry. 2009;48(4):380-5.

12. Thapar A, Collishaw S, Pine DS, Thapar AK. Depression in adolescence. Lancet. 2012:379(9820):1056-67.

13. Anda RF, Felitti VJ, Bremner JD, Walker JD, Whitfield C, Perry BD, et al. The enduring effects of abuse and related adverse experiences in childhood. A convergence of evidence from neurobiology and epidemiology. Eur Arch Psychiatry Clin Neurosci. 2006;256(3):174-86.

14. Turner HA, Finkelhor D, Ormrod R. The effect of lifetime victimization on the mental health of children and adolescents. Soc Sci Med. 2006;62(1):13-27.

15. Indonesia Basic Health Research (RISKESDAS). Agency of Health Research and Development (Indonesia). Jakarta. 2013.

16. Kovacs M. Children's depression inventory (CDI). Toronto: Multi-Health Systems Inc:; 1992.

17. Kovacs M. Children's depression inventory 2nd edition (CDI2). North Tonawanda: Multi-Health Systems Inc; 2010.

18. Widhiarso W, Retnowati S. Investigasi butir bias jender dalam pengukuran depresi melalui Children's Depression Inventory (CDI). Jurnal Penelitian Psikologi. 2011;2(1):1-10.

19. Runyan DK, Dunne MP, Zolotor AJ. Introduction to the development of the ISPCAN child abuse screening tools. Child Abuse Negl. 2009;33(11):842-5.

20. Zolotor AJ, Runyan DK, Dunne MP, Jain D, Peturs HR, Ramirez C, et al. ISPCAN child abuse screening tool Children's version (ICAST-C): instrument development and multi-national pilot testing. Child Abuse Negl. 2009; 33(11):833-41

21. Dhamayanti M, Rachmawati AD, Arisanti N, Setiawati EP, Rusmi VK, Sekarwana N. Validitas dan Reliabilitas Kuesioner Skrining Kekerasan terhadap Anak "ICAST-C" versi Bahasa Indonesia. Jurnal Keperawatan Padjadjaran. 2018;5(3) (2017): Jurnal Keperawatan Padjadjaran DO 1024198/jkpv5i3650.

22. UNICEF. Measuring-violence-against-children---inventory-and-assessment-ofquantitative-studies. In: United Nations Children's Fund Division of Data Research and Policy; October 2014.
23. Radzik M, Sherer S, Neinstein LS. Psychosocial development in normal adolescents. In: Neinstein LS, Gordon CM, Katzman DK, Rosen DS, Woods ER, editors. Adolescent Health Care. 6th ed. Philadelphia: Lippincot William \& Wilkins, aWolters Kluwer; 2009. p. 27-31.

24. Infurna MR, Reichl C, Parzer P, Schimmenti A, Bifulco A, Kaess M. Associations between depression and specific childhood experiences of abuse and neglect: a meta-analysis. J Affect Disord. 2016;190:47-55.

25. Costello E, Copeland W, Angold A. Trends inpsychopathology across the adolescent years: what changeswhen children become adolescents, and when adolescentsbecome adults? J Child Psychol Psychiatry. 2011;52(10): 1015-25.

26. Nemeroff C. Paradise Lost: The Neurobiological and ClinicalConsequences of Child Abuse and Neglect. Neuron. 2016;9(2):892.

27. Segrin C. Social skills deficits associated with depression. Clin Psychol Rev. 2000;20(3):379-403.

28. Pirdehghan A, Vakili M, Rajabzadeh Y, Puyandehpour M, Aghakoochak A. Child abuse and mental disorders in Iranian adolescents. Iran J Pediatr. 2016; 26(2):e3839.

29. Strathearn L. Maternal neglect: oxytocin, dopamine and the neurobiology of attachment. J Neuroendocrinol. 2011;23:1054-65.

30. Nelson J, Klumparendt A, Doebler P, Ehring T. Childhood maltreatment and characteristics of adult depression: meta-analysis. Br J Psychiatry. 2017;210: 96-104.

31. Mills R, Kisely S, Alati R, Strathearn L, Najman J. Self-reported and agency notified child sexual abuse in a population-based birth cohort. J Psychiatr Res. 2016;74:87-93.

32. Rao U, Hammen CL, Poland RE. Longitudinal course of adolescent depression: neuroendocrine and psychosocial predictors. J Am Acad Child Adolesc Psychiatry. 2010;49(2):141-51.

33. Perepletchikova. On the topic of treatment integrity. Clin Psychol Sci Prac 2011;18(2):148-153.

\section{Publisher's Note}

Springer Nature remains neutral with regard to jurisdictional claims in published maps and institutional affiliations.
Ready to submit your research? Choose BMC and benefit from:

- fast, convenient online submission

- thorough peer review by experienced researchers in your field

- rapid publication on acceptance

- support for research data, including large and complex data types

- gold Open Access which fosters wider collaboration and increased citations

- maximum visibility for your research: over $100 \mathrm{M}$ website views per year

At BMC, research is always in progress.

Learn more biomedcentral.com/submissions 